Smolinsky, E., Tumbleson, M. E., Meade, R. J. Hanson L. E. \& Aunan W. J. (1963). Y. Anim. Sci. 22, II3I.

Sarensen, H. P. (1961). Arsberetn. Inst. Sterilitetsforskn. K. vet.-LandbHagsk., Kbh. p. ${ }_{1} 8_{5}$.

Sørensen, H. P. (1962). Proc. Easter Sch. agric. Sci., Univ. Nott., 196 1 p. 88.

Sterba, A. (1964). Sb. vys. Sk. zeméd. Brne. Sect. A, Mechanisace (part 3), 391.

Stevermer, E., Kovacs, M. F., Jr., Hoekstra, W. G. \& Self, H. L. (1959). F. Anim. Sci. 18, 1488.

Stevermer, E. J., Kovacs, M. F., Jr, Hoekstra, W. G. \& Self, H. L. (Ig6r). F. Anim. Sci. 20, 858.

Stothers, S. C. (1963). F. Anim. Sci. 22, 113 I.

Supek, Z., Szecsenyi, A. \& Levay, M. (1964). Bull. Fac. Agric. Sci., Gödöllo no. 9 I.

Szecsenyi, A. (196z). Bull. Fac. Agric. Sci, Gödöllo no. 147.

Szigeti, J. (1956). Allattenyésztés, 5, 3.

Tardani, A. \& Lux, B. (I963). Riv. Zootec. 36, 598.

Tardani, A., Lux, B. \& Del Monte, R. (1964). Riv. Zootec. 37, 669.

Taylor, M. E., Pickett, R. A., Issacs, G. W. \& Foster, G. (I964). F. Anim. Sci. 23, 894.

Teague, H. S., Grifo, A. P. Jr \& Rutledge, E. A. (1966). J. Anim. Sci. 25, 693.

Teague, H. S. \& Rutledge, E. A. (I 96o). Feedstuffs, Minneap. 32, 70.

Teague, H. S. \& Wilson, R. F. (1957). Res. Circ. Ohio agric. Exp. Stn no. 46.

Thomas, O. O. \& Flower, A. E. (1956). Circ. Mont. agric. Exp. Stn no. 214.

Thrasher, D. M. (1963). F. Anim. Sci. 22, 241.

Thrasher, D. M., Mullins, A. M. \& Newman, C. W. (r96r). F. Anim. Sci. 20, 39r.

Thrasher, D. M., Mullins, A. M. \& Newman, C. W. (1963). F. Anim. Sci. 22, 243.

Thrasher, D. M., Roberts, H. P. \& Mullins, A. M. (1964). F. Anim. Sci. 23, 895 .

Thrasher, G. W., Henson, L. N. \& Bogdonoff, P. D. (1963). Feedstuffs, Minneap. 35, 26.

Todd, A. C. E., (1964). Qd agric. F. 9o, r3 ז.

Todd, A. C. E. \& Daniels, L. J. (1966). Aust. F. exp. Agric. Anim. Husb. 6, 452.

Tomson, E. G. (1965). Vestn. sel'.-khoz. Nauki, Mosk. no. 6, 89.

Tribble, L. F., Pfander, W. H., Lasley, J. F., Zobrisky, S. E. \& Brady, D. E. (1956). Res. Bull. Mo agric. Exp. Stn no. 609 .

Tschiderer, K. (1956). Arch. Tierernähr. 6, 44.

Vanschoubroek, F. X., de Wilde, R. O. \& Van Spaendonck, R. L. (1965). Anim. Prod. 7, IrI.

Veum, T. L., Pond, W. G. \& Walker, E. J. Jt (1966). Mimeogrs Cornell Univ. Swine Division no. 66.

Wallace, H. D., Houser, R. H. \& Combs, G. E. (1966). I Ith Annual Swine Field Day, University of Florida, $A N 67-2$.

Wallace, H. D., Palmer, A. Z., Carpenter, J. W., Anh, N. H. \& Combs, G. E. (1964). J. Anim. Sci. 23, 299.

Wallace, H. D., Palmer, A. Z., Carpenter, J. W. \& Combs, G. E. (1966). Bull, Fla agric. Exp. Stn no. 706.

Watson, M. F. (1963). E. Afr. agric. For. F. 28, г68.

Weber, E. \& Kaiser, W. (1958-9). भb. Arbeitsgemeinsch. Fütterungsberat. 2, 153.

Weniger, J. H. (1961). Z. Tierphysiol. Tierernähr. Futtermittelk. 16, 153.

Witt, M., Andrea, U. \& Schröder, J. (1957). Züchtungskunde, 29, 142.

Witt, M., Andreae, U. \& Schröder, J. (1964). Fleischwirtschaft, 44, 314.

Yeo, M. L. \& Chamberlain, A. G. (1966). Proc. Nutr. Soc. 25, xli.

Zausch, M. (1963). 7. Arbeitsgemeinsch. Fütterungsberat. 4, 1961-62, 186.

Zednik, M. (1964). Sb. vys. Šk. zeméd. Brne, Rada A, no. 3, p. 401 .

Zimmerman, D. R., Spies, H. G., Rigor, E. M., Self, H. L. \& Casida, L. E. (1960). F. Anim. Sci. x9, 687.

Zivkovic, S. (1959). Veterinaria, Saraj. 8, 101.

\title{
Effect of frequency of feeding upon food utilization by ruminants
}

\author{
By A. W. A. Bur't and C. R. Dunton, Unilever Research Laboratory, \\ Colworth House, Sharnbrook, Bedford
}

\section{Introduction}

Feeding pattern may be defined as the distribution of food intake over time. As such the term covers many widely divergent aspects of ruminant nutrition. 
This paper deals mainly with one facet of ruminant feeding patterns, that is diurnal variation in the distribution of a controlled food supply. Other well-recognized aspects of feeding patterns, such as seasonal and year-to-year variations in food supply under extensive grazing, compensatory growth, grazing behaviour and effects of physical form of the diet will not be discussed.

Since total gut contents form a much greater percentage of live weight in ruminants than in simple-stomached animals and since their food, particularly the fibrous materials present, is retained longer and digested more slowly than the simpler compounds fed to non-ruminants, it might be expected that ruminants would be quite resistant to changes in the daily feeding pattern. On the other hand, the presence of a vast, dense and active microbiological population in the forestomach which regularly produces large quantities of steam volatile acids is well known in practice to lead to disastrous results if the animal suddenly ingests very large quantities of highly available substrates at one meal. The pattern of daily food supply is therefore of some practical importance, especially if the cost of dividing it into portions is remembered.

\section{Growth}

Although Mochrie (1964) in an earlier review concluded that feeding more frequently than once or twice daily generally improved the live-weight gain of growing ruminants, there are numerous carefully controlled experiments which fail to show such responses. In some experiments, growth responses obtained could be largely attributed to increased food intake; for instance Mohrman, Albert, Neuman n \& Mitchell (I959) obtained increases in the live-weight gain and food intake of steers fed high-energy diets six times instead of twice daily.

Experiments conducted on growing sheep, in which daily food intakes appear to have been satisfactorily equalized are shown in Table $I$ and those on growing cattle in Table 2. These tables list the rations used, the number of feeds and the length of the 'feeding day' over which these were distributed. Length of experimental period is shown, and the factor ' $2 \times$ ' indicates those experiments in which a changeover design with two periods was used.

Table I lists seven experiments with sheep. Positive responses were reported in two of them, namely those of Gordon \& Tribe (I 952) who appreciably increased live-weight gain from a very low level by feeding eight times instead of once daily. Rakes, Lister \& Reid (196r) showed responses in live-weight gain when feeding frequency was increased from once to eight times daily in lambs aged 6 months, but not in ewes aged 2-5 years and considered that increasing age eliminated the response. On the other hand, Rhodes \& Woods ( 1962 ), who determined live weight after fasting, got no significant or appreciable response in a series of four experiments using ground and mixed, pelleted or conventional rations containing different proportions of roughage.

A similar preponderance of negative results $(7: 4)$ is shown for cattle in Table 2. Rakes, Hardison, Albert, Moore \& Graf (1957) and Putnam, Gutierrez \& Davis 
Table I. Trials on frequency of feeding with growing sheep

\begin{tabular}{|c|c|c|c|c|c|}
\hline Authors & Ration & $\begin{array}{l}\text { Approx. } \\
\text { initial } \\
\text { live } \\
\text { weight }(\mathrm{kg})\end{array}$ & $\begin{array}{l}\text { No. of } \\
\text { feeds } \\
\text { daily }\end{array}$ & $\begin{array}{c}\text { Time } \\
\text { first to last } \\
\text { feed (h) }\end{array}$ & $\begin{array}{l}\text { Live- } \\
\text { weight } \\
\text { gain } \\
\text { (kg/day) }\end{array}$ \\
\hline
\end{tabular}

Trials giving positive responses

Gordon \& Tribe Hay $0.45 \mathrm{~kg}$, concentrates 34 (I952) $0.68 \mathrm{~kg}$

34

Rakes, Lister \& 50\% chopped hay, 50\% (Age 6 months)

I
8

$\begin{array}{rll}24 & 0.02 & 2 \times 63 \\ 8 & 0.08 & \\ 24 & 0.10 & 2 \times 49 \\ 10 & 0.16 & \end{array}$

Trials giving no response

\begin{tabular}{|c|c|c|c|c|c|c|}
\hline \multirow{12}{*}{$\begin{array}{l}\text { Rhodes \& } \\
\text { Woods (1962) }\end{array}$} & \multirow{3}{*}{$\begin{array}{l}\text { Pelleted } 67 \% \text { concentrates, } \\
\quad 37 \% \text { hay }\end{array}$} & \multirow[t]{3}{*}{34} & 2 & II & 0.13 & \multirow{3}{*}{54} \\
\hline & & & 4 & I I & 0.17 & \\
\hline & & & 6 & I I & 0.12 & \\
\hline & \multirow{3}{*}{$\begin{array}{l}50 \% \text { hay, } 50 \% \text { concen- } \\
\text { trates ground and mixed }\end{array}$} & \multirow[t]{3}{*}{$3 I$} & 2 & II & 0.12 & \multirow{3}{*}{84} \\
\hline & & & 4 & I I & 0.15 & \\
\hline & & & 6 & II & 0.15 & \\
\hline & \multirow{3}{*}{$\begin{array}{c}49 \% \text { or } 74 \% \text { concentrates, } \\
51 \% \text { or } 26 \% \text { hay }\end{array}$} & \multirow[t]{3}{*}{29} & 2 & 12 & 0.19 & \multirow{3}{*}{70} \\
\hline & & & 4 & 12 & 0.18 & \\
\hline & & & $\begin{array}{l}4 \\
6\end{array}$ & $\begin{array}{l}24 \\
24\end{array}$ & $\begin{array}{l}0.18 \\
0.17\end{array}$ & \\
\hline & \multirow{3}{*}{$\begin{array}{l}50 \% \text { brome or alfalfa hay, } \\
50 \% \text { concentrates }\end{array}$} & \multirow{3}{*}{37} & 2 & 8 & 0.13 & \multirow{3}{*}{54} \\
\hline & & & 4 & I 2 & 0.12 & \\
\hline & & & 6 & 24 & 0.12 & \\
\hline $\begin{array}{l}\text { Rakes et al. } \\
\quad(196 \mathrm{r})\end{array}$ & $\begin{array}{l}50 \% \text { hay, } 50 \% \text { concen- } \\
\text { trates }\end{array}$ & $\begin{array}{l}\text { Age } 2-5 \\
\text { years) }\end{array}$ & $\begin{array}{l}1 \\
8\end{array}$ & $\begin{array}{l}24 \\
10\end{array}$ & $\begin{array}{l}0.08 \\
0.08\end{array}$ & $2 \times 49$ \\
\hline
\end{tabular}

*' $2 \times$ ' indicates an experiment in which a changeover design was used.

Table 2. Trials on frequency of feeding with growing cattle

\begin{tabular}{|c|c|c|c|c|c|c|}
\hline Authors & Ration & $\begin{array}{l}\text { Approx. } \\
\text { initial } \\
\text { live } \\
\text { weight (kg) }\end{array}$ & $\begin{array}{l}\text { No. of } \\
\text { feeds } \\
\text { daily }\end{array}$ & $\begin{array}{l}\text { Time } \\
\text { first to last } \\
\text { feed (h) }\end{array}$ & $\begin{array}{l}\text { Live- } \\
\text { weight } \\
\text { gain } \\
\text { (kg/day) }\end{array}$ & $\begin{array}{l}\text { Experi- } \\
\text { mental } \\
\text { period* } \\
\text { (days) }\end{array}$ \\
\hline & (a) Trials gi & giving positiv & e response & & & \\
\hline \multirow{4}{*}{$\begin{array}{l}\text { Rakes et al. } \\
\quad \text { (r957) } \\
\text { Mochrie et al. } \\
\quad(\mathrm{r} 956)\end{array}$} & \multirow{2}{*}{\multicolumn{2}{|c|}{$\begin{array}{l}\text { Chopped alfalfa orchard I80 } \\
\text { grass hay } 5.1 \mathrm{~kg}\end{array}$}} & 2 & 9 & 0.22 & \multirow{2}{*}{$2 \times 50$} \\
\hline & & & 5 & 9 & 0.43 & \\
\hline & \multirow{2}{*}{$\begin{array}{l}\text { Concentrates } 1.8 \mathrm{~kg} \text {, hay } \\
2.9 \mathrm{~kg}\end{array}$} & \multirow[t]{2}{*}{145} & $\mathbf{I}$ & 24 & 0.47 & \multirow{2}{*}{$2 \times 42$} \\
\hline & & & 4 & 12 & 0.55 & \\
\hline \multirow{2}{*}{$\begin{array}{l}\text { Putnam et al. } \\
\text { (I96I) }\end{array}$} & \multirow[t]{2}{*}{ Ground alfalfa hay } & \multirow[t]{2}{*}{135} & 2 & 9 & 0.25 & \multirow{2}{*}{$2 \times 87$} \\
\hline & & & 10 & 9 & 0.34 & \\
\hline \multirow[t]{2}{*}{$\begin{array}{l}\text { Campbell et al. } \\
\quad(1963)\end{array}$} & $\begin{array}{l}\text { Concentrates }+ \text { urea } 2.5 \mathrm{~kg} \text {; } \\
\text { hay } 3.2 \mathrm{~kg}\end{array}$ & I 45 & $\begin{array}{l}2 \text { (conc.) } \\
6 \text { (conc.) }\end{array}$ & $\begin{array}{r}9 \\
15\end{array}$ & $\begin{array}{l}0.55 \\
0.69\end{array}$ & 112 \\
\hline & \multirow{3}{*}{$\begin{array}{l}\text { Concentrates, hay and } \\
\text { brewer's grains } \\
\text { Concentrates, hay and } \\
\text { brewer's grains }\end{array}$} & als giving no & response & & & \multirow[b]{2}{*}{$2 \times 50$} \\
\hline \multirow[t]{2}{*}{$\begin{array}{l}\text { Anonymous } \\
\quad(1958)\end{array}$} & & $\begin{array}{l}\text { (Age 6-12 } \\
\text { months) }\end{array}$ & $\begin{array}{l}\mathbf{1} \\
\mathbf{2}\end{array}$ & 24 & $\begin{array}{l}0.59 \\
0.60\end{array}$ & \\
\hline & & $\begin{array}{l}\text { (Age 6-12 } \\
\text { months) }\end{array}$ & $\begin{array}{l}\mathrm{I} \\
6\end{array}$ & $\begin{array}{r}24 \\
?\end{array}$ & $\begin{array}{l}0.73 \\
0.76\end{array}$ & $2 \times 50$ \\
\hline \multirow[t]{5}{*}{$\begin{array}{l}\text { Clark \& Keener } \\
\text { (1962) }\end{array}$} & $\begin{array}{l}\text { Hay to } 10 \% \text { refusal, con- } \\
\text { centrates } \mathrm{I} \cdot \mathrm{I} \mathrm{kg}\end{array}$ & -125 & $\begin{array}{r}2 \\
24\end{array}$ & $\begin{array}{r}9 \\
24\end{array}$ & $\begin{array}{l}0.69 \\
0.69\end{array}$ & 245 \\
\hline & $\begin{array}{l}\text { Hay restricted, soya-bean } \\
\text { meal } 0.25 \mathrm{~kg}\end{array}$ & $300 ?$ & $\begin{array}{r}2 \\
10\end{array}$ & $\begin{array}{l}9 \\
9\end{array}$ & $\begin{array}{l}0.35 \\
0.39\end{array}$ & 60 \\
\hline & \multirow{2}{*}{$\begin{array}{l}\text { Hay to } 10 \% \text { refusal, soya- } \\
\text { bean meal } 0.34 \mathrm{~kg}\end{array}$} & $200 ?$ & 2 & 9 & 0.82 & \multirow{2}{*}{60} \\
\hline & & & 10 & 9 & $0.8 I$ & \\
\hline & $\begin{array}{l}\text { Restricted hay, soya-bean } \\
\text { meal } 0.34 \mathrm{~kg}\end{array}$ & $250 ?$ & $\begin{aligned} 2 \\
10\end{aligned}$ & $\begin{array}{l}9 \\
9\end{array}$ & $\begin{array}{l}0.74 \\
0.68\end{array}$ & 60 \\
\hline $\begin{array}{l}\text { Campbell et al. } \\
\text { (1963) }\end{array}$ & $\begin{array}{l}\text { Concentrates } 2.7 \mathrm{~kg} \text {, hay } \\
3.0 \mathrm{~kg} \text { approx. }\end{array}$ & 145 & $\begin{array}{l}2 \\
6\end{array}$ & $\begin{array}{r}9 \\
15\end{array}$ & $\begin{array}{l}0.71 \\
0.75\end{array}$ & $\mathbf{1} 12$ \\
\hline
\end{tabular}


(196r) obtained substantial responses in live-weight gain when the frequency of feeding chopped or ground hays was increased from two to five or ten times in a $9 \mathrm{~h}$ day in reversal trials. Mochrie, Thomas \& Lucas (1956) obtained responses when the frequency of feeding a mixed diet was increased from once to four times daily in a reversal trial with Holstein steers.

The results of the experiment of Campbell, Howe, Martz \& Merilan (1963) on forty Guernsey heifers fed grain mixtures containing urea or soya-bean meal twice or six times daily have been divided into two parts in Table 2. The diet containing urea which gave a response to increased frequency is shown in part (a) of Table 2 and the part in which soya-bean meal was used, which gave no significant response, is shown in part (b). There were some differences in food intakes between animals fed twice and six times daily in both instances. The system used for the feeding of the hay was not described in detail, but was stated to be on a group basis, while concentrates were individually fed.

Apart from the negative response to more frequent feeding in part of the experiment of Campbell et al. (1963), negative responses were also reported by workers at Shinfield (Anonymous, 1958) using identical twin heifers in two reversal experiments and in a series of four experiments carried out by Clark \& Keener (1962), who concluded that responses only occurred when the diet was restricted and that these disappeared after the Ist month of feeding. Although Horton (1964) also obtained no response to feeding concentrates twice or four or eight times between 07.00 and $17.00 \mathrm{~h}$, values from this experiment were not included in Table 2 because hay, water and salt were offered ad lib. during the night from 17.00 to $07.00 \mathrm{~h}$. More recently, Raleigh \& Wallace (1965), in a very brief report, noted that increased frequency of feeding improved response only in calves given low-energy, high-nitrogen diets, as distinct from other combinations of high or low energy and nitrogen. In this experiment a major proportion of the nitrogen was provided by urea.

With both sheep and cattle, therefore, the majority of experiments on growth have shown no response to increasing feeding frequency and it is possible to discern a dietary pattern in those in which responses occurred. In some of the latter experiments, the control treatment was feeding once daily (Gordon \& 'Tribe, 1952; Rakes et al. 1961; Mochrie et al. 1956), in others.roughage supplied the whole of the diet (Putnam et al. 196I; Rakes et al. I957) and in the remainder urea was included in the diet (Campbell et al. 1963). The only trials in which increasing the frequency from once-daily feeding failed to produce a response were those with identical twins at Shinfield (Anonymous, 1958) and of Rakes et al. (196I) with mature sheep.

One may conclude, therefore, that the growing ruminant will often respond to increasing the frequency of feeding from once to twice daily, but that response to further increases in frequency are governed by the nature of the diet and are unlikely to occur in animals fed sufficient roughage and concentrates to give reasonable liveweight gains.

\section{The lactating cow}

Since increased frequency of feeding sometimes improves the utilization of the 
diet of growing ruminants it might be expected that sizeable responses would occur in the lactating cow, because of its generally greater relative energy turnover. Similarly, the practical consequences of giving too much concentrates in one feed, which can rapidly lead to inappetence, are well known and might lead one to expect a response from more frequent feeding. There are, however, few well-established reports of such effects.

Although Campbell \& Merilan ( 1960) obtained higher milk yields when frequency of feeding was increased from twice to four or seven times daily, these could be attributed to increased food intake. Mochrie et al. (1956) raised the frequency of feeding from twice to four or eight times daily without influencing milk yield or composition, but heifers in their first lactation were used, which may have been less responsive than older animals. Johnson, Trimberger, Wright, Van Vleck \& Henderson (I966) have recently reported that cows fed hay and maize silage twice to five times daily ate less and produced more efficiently in mid-lactation than when fed once daily. We have carried out several carefully controlled experiments, using restricted intakes of roughage and concentrates, which will now be described, and which generally failed to show any benefit from increasing the feeding frequency above that normally practised in the herd in question.

\section{'Table 3. Experiments on the frequency of feeding lactating cows}

\begin{tabular}{|c|c|c|c|c|c|c|c|c|}
\hline \multirow{3}{*}{$\begin{array}{c}\text { Expt } \\
\text { no. }\end{array}$} & \multicolumn{2}{|c|}{ Treatment } & \multirow{3}{*}{$\begin{array}{c}\text { Milk } \\
\text { yield } \\
\text { (kg/day) }\end{array}$} & \multirow{2}{*}{\multicolumn{3}{|c|}{ Percentage in milk }} & \multirow{3}{*}{$\begin{array}{c}\text { Live } \\
\text { weight } \\
\text { (kg) }\end{array}$} & \multirow{3}{*}{$\begin{array}{c}\text { Pulse } \\
\text { rate } \\
\text { (beats/ } \\
\text { min) }\end{array}$} \\
\hline & \multirow{2}{*}{$\begin{array}{l}\text { No. of } \\
\text { meals daily }\end{array}$} & \multirow{2}{*}{$\begin{array}{l}\text { Position of } \\
\text { cows }\end{array}$} & & & & & & \\
\hline & & & & Fat & Protein & Lactose & & \\
\hline \multirow[t]{2}{*}{$\mathbf{I}$} & $\begin{array}{l}4 \text { (normal) } \\
\text { Io (equal) }\end{array}$ & - & $\begin{array}{l}10.52 \\
10.66\end{array}$ & $\begin{array}{l}4.03 \\
4.01\end{array}$ & $\begin{array}{l}3.19 \\
3.20\end{array}$ & $\begin{array}{l}4.63 \\
4.70\end{array}$ & $\begin{array}{l}419^{\circ} 1 \\
420^{\circ} 0\end{array}$ & $\begin{array}{l}63.0 \\
68.8\end{array}$ \\
\hline & $\begin{array}{l}\text { Significant di } \\
\quad(P=0.05)\end{array}$ & fference & 0.16 & 0.08 & 0.04 & 0.06 & $2 \cdot 0$ & $I \cdot 4$ \\
\hline \multirow[t]{4}{*}{2} & Io (equal) & - & $6 \cdot 49$ & $4 \cdot 39$ & 3.49 & $4 \cdot 37$ & $43 I^{\circ} 7$ & $59 \cdot 2$ \\
\hline & 4 (normal) & Adjacent & $6 \cdot 43$ & $4 \cdot 47$ & $3 \cdot 46$ & $4 \cdot 28$ & $437 \cdot 7$ & 60.5 \\
\hline & 4 (normal) & Different shed & $5 \cdot 80$ & $4 \cdot 3^{6}$ & $3 \cdot 58$ & $4 \cdot 23$ & $43^{8 \cdot I}$ & 60.5 \\
\hline & $\begin{array}{l}\text { Significant di } \\
\qquad(P=0.05)\end{array}$ & fference & 0.83 & 0.23 & 0.21 & 0.15 & $4 \cdot 3$ & $2 \cdot 0$ \\
\hline \multirow[t]{6}{*}{3} & Io (equal) & - & $15 \cdot 25$ & $3 \cdot 72$ & 3.19 & $4 \cdot 64$ & $476 \cdot 8$ & - \\
\hline & 4 (normal) & Adjacent & 15.62 & $3 \cdot 76$ & $3 \cdot 16$ & 4.65 & $48 r \cdot 5$ & - \\
\hline & 4 (normal) & Distant same shed & $15 \cdot 95$ & $3 \cdot 61$ & $3 \cdot 16$ & $4 \cdot 66$ & $483 \cdot I$ & - \\
\hline & 4 (normal) & Different shed & 16.06 & $3 \cdot 65$ & $3 \cdot 15$ & $4 \cdot 69$ & $48 z \cdot 9$ & - \\
\hline & 4 (equal) & Different shed & $15 \cdot 72$ & $3 \cdot 72$ & $3 \cdot 19$ & $4 \cdot 69$ & $477 \cdot 4$ & - \\
\hline & $\begin{array}{l}\text { Significant di } \\
\quad(P=0.05)\end{array}$ & fference & 0.65 & 0.17 & 0.05 & 0.10 & $4 \cdot 4$ & 一 \\
\hline
\end{tabular}

The results of these experiments are shown in Table 3. In all of them a basal constant diet of $5 \mathrm{~kg}$ hay and $9 \mathrm{~kg}$ grass silage was fed for maintenance with adjustments to take account of individual live weight. Concentrates were fed for production at $4 \mathrm{~kg} /$ ro $\mathrm{kg}$ milk, using the equalized feeding system of Lucas (I943). The normal feeding routine in this herd already provided four daily meals, namely half the concentrates at $05.30 \mathrm{~h}$, silage at $\mathrm{II} .00 \mathrm{~h}$, half the concentrates at $\mathrm{I} 5.00 \mathrm{~h}$ and hay at $17.30 \mathrm{~h}$. In the experimental routine, the whole of the daily food allocation was 
divided into approximately equal meals fed at $05.3^{\circ}, 07.30$, I I.00, I2.00, I3.00, $14.00,15.00,16.00,17.30$ and $21.00 \mathrm{~h}$.

In Expt I, ten cows were used in a double-reversal design with 3 -week experimental periods to compare the effects of normal, and ten times daily feeding of cows housed adjacently. There were no significant effects upon milk production, but the percentage of lactose was increased by increased feeding frequency. Pulse rates measured at $\mathrm{r} 4.30 \mathrm{~h}$ were also increased but this was attributed largely to the effects of redistribution of food intake, which provided higher intakes of roughage and total dry matter before the determination in cows fed more frequently. During this experiment it was observed that the cows fed normally were stimulated into appreciable activity when the extra feeds were given to the more frequently fed cows in adjacent standings, corresponding to the observation of Rakes et al. (I96I) of temporary increases in heat production in sheep housed alongside others fed frequently. A second experiment was therefore conducted in which cows fed ten times daily were housed alongside normal controls and then compared with other controls housed and fed in a second shed by the same staff in the same manner. There was some evidence from this experiment that the cows fed frequently, and those housed next to them, gave some response in milk yield. Yields were extremely low, probably owing to fungal contamination of the hay used (Burt, Dunton \& Thomas, 1963). A third experiment was therefore carried out which attempted to establish whether there was a real difference between cows fed ten times daily and controls fed four times daily. The control animals were housed (a) alongside, (b) distantly but in the same shed or (c) in the second shed. The effects of feeding the diet as four equal feeds instead of the four different feeds of roughage and concentrates were also tested. Five treatments were compared using fifteen cows and $5 \times 4$ week periods in a latin square design. The results of this experiment showed that milk yield was lower on ten times daily feeding, significantly lower than on the two distant control treatments, with the adjacent control and four times feedingequal feeds intermediate. Live weights were lower in cows fed ten equal portions or four times equal portions than on all other treatments. We must therefore conclude that there are no significant responses to be obtained from more frequent feeding of dairy cows, other than those to be achieved by, sensible distribution of concentrate intake to avoid digestive disturbance. It is encouraging also to note that we have found no significant difference between the two cowsheds.

Bloomfield, Welsch, Garner \& Muhrer (1961) reported that feeding a diet containing urea sixteen times daily instead of twice to lambs improved the utilization of nitrogen, and Campbell et al. (1963) reported that there was no difference in growth or the efficiency of utilization of diets containing soya-bean meal or urea when these were fed six times daily, but that there was a substantial difference in live-weight gain in favour of soya-bean meal when the diets were fed twice daily. In a further experiment we therefore examined the effects of frequent feeding with diets containing urea (Table 4 ). In this experiment, the urea treatments depressed the percentages of milk fat and lactose, but increased the percentage of milk protein. The depression in total milk output approached significance. Frequency 
Table 4. Effect of feeding frequency upon the utilization of urea by lactating cows

\section{Treatment}

(1) Urea twice daily, roughages twice daily

(2) Urea and roughages ten times daily

(3) Vegetable protein and roughages fed as in (I) Significant difference $(P=0.05)$

\begin{tabular}{|c|c|c|c|c|}
\hline \multirow{2}{*}{$\begin{array}{l}\text { Milk } \\
\text { yield } \\
\text { (kg/day) }\end{array}$} & \multicolumn{3}{|c|}{ Percentage in milk } & \multirow{2}{*}{$\begin{array}{c}\text { Live } \\
\text { weight } \\
(\mathrm{kg})\end{array}$} \\
\hline & Fat & Lactose & Protein & \\
\hline $\begin{array}{l}15.69 \\
15.66\end{array}$ & $\begin{array}{l}3.51 \\
3.53\end{array}$ & $\begin{array}{l}4 \cdot 86 \\
4 \cdot 88\end{array}$ & $\begin{array}{l}3.07 \\
3.11\end{array}$ & $\begin{array}{l}458 \cdot 1 \\
455 \cdot 8\end{array}$ \\
\hline 15.99 & 3.73 & 4.94 & 3.00 & $458 \cdot 5$ \\
\hline 0.35 & $0 \cdot 11$ & 0.07 & 0.05 & $2 \cdot 3$ \\
\hline
\end{tabular}

of feeding had no appreciable or significant effect upon the response to urea, except to depress live weight measured at Ir.00 h.

We therefore conclude that increased frequency of feeding is not effective in overcoming the depression of milk production which usually occurs on diets containing urea.

In all four experiments differences in mean live weight related to changes in feeding frequency were recorded which were significant or nearly so. We were able to relate these to differences in dry-matter intake during the morning before recording weight at $\mathrm{I} I .00 \mathrm{~h}$ in three out of four cases. This illustrates the care with which apparent effects of feeding frequency upon live weight or any other characteristic measured once daily must be interpreted.

\section{General effects on food utilization}

Zero, positive or negative responses in the digestibility of the diet to increased frequency of feeding have all been reported. No responses were obtained by Blaxter, Graham \& Wainman (1956) when sheep were fed equal amounts of dried grass at 24 , 12 or 6 hourly intervals or by Satter \& Baumgardt (1962) or Rhodes \& Woods (1962).

Rakes et al. (1957) reported that feeding ten times daily significantly depressed the digestibility of the dry matter, nitrogen, crude fibre and nitrogen-free extract by $1-4 \%$ compared with twice daily feeding of mixed hay. McGuire, Bradley \& Little (1966) obtained a similar result for nitrogen in steers fed six times instead of once daily, but found slight, though not significant increases in the digestibility of crude fibre, NFE and gross energy. Moir \& Somers (1957) obtained a significant increase in dry-matter and $\mathrm{N}$ digestibility when sheep were fed concentrates, oat and lucerne chaff twice or four times daily instead of once. Mohrman et al. (1959) obtained increases in the digestibility of nitrogen and energy by more frequent feeding and Gordon \& Tribe (1952) also found a response for nitrogen in lambs fed eight times instead of once daily.

Dependence of the response upon the diet used is indicated by Sutherland, Gupta, Reid \& Murray (1963), who found that continuous feeding over the $24 \mathrm{~h}$ improved the digestibility of cubed hay, but not of dried grass, compared with feeding twice or four times daily.

Feeding more frequently evens out fluctuations in the concentration of total steam volatile fatty acids and ammonia in rumen liquor (cf. Rakes et al. 1957; 
Satter \& Baumgardt, 1962; Moir \& Somers, I957). Several experiments have shown slightly lower mean pH levels (Rakes et al. 1957; Knox \& Ward, 1960). Increased proportions of propionic acid in total steam volatile fatty acids have been reported in samples taken hourly over $24 \mathrm{~h}$ from cattle fed a maintenance ration eight times instead of twice daily (Knox \& Ward, I960). Sutherland et al. (1963) found that continuous feeding did not alter the total production of steam volatile fatty acids per unit organic matter digested in the rumen of sheep, but increased the percentage of propionic acid in the steam volatile fatty acids. Concrete evidence that completely regular feeding of equal amounts at hourly intervals to sheep kept at a constant temperature, at constant illumination and at a constant level of noise eliminates diurnal variation of faecal dry-matter output and concentration, of flow, specific gravity and nitrogen concentration of urine, and of total nitrogen excretion in urine, has recently been provided by Minson \& Cowper (1966). More even concentrations of ammonia in rumen liquor would be expected to increase the efficiency of nitrogen utilization, by reducing losses by absorption at peak levels, and improvements in nitrogen retention have been reported by Gordon \& Tribe (I952), Moir \& Somers (1957), Rakes et al. (I961) and Satter \& Baumgardt (1962).

Brody (1945) suggested that heat losses might be reduced by more frequent feeding to prevent substantial peaks of heat production and more recently Payne (I966) has suggested that high-producing animals in the tropics should be fed as frequently as possible through the $24 \mathrm{~h}$ to spread heat increment and give less likelihood of overloading heat dissipation mechanisms. However, Blaxter et al. (1956) found that increased feeding frequency had no significant effect upon total heat production, but increased methane production significantly by about I kcal/roo kcal ingested energy. Rakes et al. ( 1961 ) also found little difference in the total heat production of sheep fed once, four or eight times daily, but found a considerable diurnal fluctuation related to feeding frequency. Sheep fed once daily adjacent to frequently fed sheep also produced more heat during the hours of feeding than when housed at a distance, but the difference was compensated during the night in the absence of food.

In two experiments counts of rumen protozoa have been shown to be increased by feeding more than once daily. Putnam et al. (Ig6I) found that feeding ten times daily almost doubled counts of Entodinitum after 8 weeks of experiment, and Moir \& Somers (1957) reported an increase in ciliate protozoa from $1 \cdot 15 \times 10^{6} / \mathrm{ml}$ in animals fed once daily to $2 \cdot 26-2 \cdot 34 \times 10^{6} / \mathrm{ml}$ in animals fed twice daily to $3 \cdot 14 \times 10^{6} /$ $\mathrm{ml}$ in animals fed four times daily.

These results may be related to the rate of flow of digesta from the rumen. Sutherland et al. (1963) found that continuous feeding reduced the volume of rumen contents, the quantity of dry matter in the rumen and the rate of outflow to the abomasum but increased the fractional hourly clearance of rumen contents. Blaxter et al. (I956) and Rakes et al. (I957) found no effect of increased feeding frequency on overall rates of passage. Harrison \& Hill (1962) reported that the rate of flow of digesta from the abomasum increased almost threefold when sheep were fed three times instead of once daily, but their observations did not cover the whole $24 \mathrm{~h}$. 
Compensatory lower flows during the night in animals previously fed more frequently might result in higher concentrations of protozoa being present at counts taken the following morning (Moir \& Somers, 1957), while the counts of Putnam et al. (1961) were taken after the first one-tenth feed for more frequently fed animals and therefore fewer protozoa may have been 'flushed out' of the rumen by the flow stimulated by feeding than in animals receiving the whole of their daily ration before the counts were taken.

The possible importance of the protozoal population should not be underrated in view of the observations of Abou Akkada \& El-Shazly (1964) and Christiansen, Kawashima \& Burroughs (1965) of increased live-weight gain, higher rumen liquor contents of reducing sugars, ammonia and steam volatile fatty acids and higher acetic to propionic ratios in faunated than in defaunated lambs.

It should be noted, however, that the effects on protozoa noted by Putnam et al. and Moir \& Somers applied only to part of the protozoal population, other species were present in fluctuating but often great numbers in the experiment of Moir \& Somers and failed to respond significantly to treatment.

Several conclusions may be drawn from this review:

Growing ruminants will often respond to increasing the feeding frequency from once to twice daily, and further response to further increases in feeding frequency may occur on low-energy diets consisting mainly of roughage, or if substantial amounts of urea are included. The concept of an interaction of diet with frequency of feeding is clearly substantiated by the observations of Sutherland et al. (1963) and Raleigh \& Wallace (1965).

These responses appear to be related to changes in the ratio of solids to liquor in the rumen, to protozoal population, and possibly to rates of saliva addition so that the utilization of nitrogen and energy is enhanced, but the precise limiting conditions for such responses to occur are not yet well defined.

There appears to be no benefit to be gained by feeding the dairy cow more frequently or more evenly than is commonly recommended, namely two to three meals of concentrates and two meals of roughage daily.

\section{REFERENCES}

Abou Akkada. A. R. \& El-Shazly, K. (1964). Appl. Microbiol. x2, 384. Anonymous (1958). Agriculture, Lond. 65, 259.

Blaxter, K. L., Graham, N. Mc \& Wainman, F. W. (1956). Proc. Nutr. Soc. 15, ii.

Bloomfield, R. A., Welsch, C., Garner, G. B. \& Muhrer, M. E. (196r). F. Anim. Sci. 20, 926.

Brody, S. (I945). Bioenergetics and Growth. New York: Reinhold Publishing Corp.

Burt, A. W. A., Dunton, C. R. \& Thomas, D. C. (I963). Anim. Prod. 6, 26 r.

Campbell, J. R., Howe, W. M., Martz, F. A. \& Merilan, C. P. (1963). F. Dairy. Sci. 46, 131.

Campbell, J. R. \& Merilan, C. P. (I960). F. Dairy Sci. 43, 872 .

Christansen, W. C., Kawashima, R. \& Burroughs, W. (1965). F. Anim. Sci. 24, 730.

Clark, B. \& Keener, H. A. (1962). F. Dairy. Sci. 45, 1199.

Gordon, J. G. \& Tribe, D. E. (1952). Br. F. Nutr. 6, 89.

Harrison, F. A. \& Hill, K. J. (1962). F. Physiol., Lond. r62, 225.

Horton, O. H. (1964). \%. Dairy Sci. 47, 196.

Johnson, W. L., Trimberger, G. W., Wright, M. J., van Vleck, L. D. \& Henderson, C. R. (1966). 7. Dairy Sci. 49, 856 .

Knox, K. L. \& Ward, G. M. (1960). F. Dairy Sci. 43, 875 . 
Lucas, H. L. (1943). F. Dairy Sci. 26, tor I.

McGuire, R. L., Bradley, N. W. \& Little, C. O. (1966). F. Anim. Sci. 25, 185.

Minson, D. J. \& Cowper, J. L. (1966). Br. F. Nutr. 20, 757.

Mochrie, R. D. (1964). Fedn Proc. Fedn Am. Socs exp. Biol. $23,85$.

Mochrie, R. D., Thomas, W. E. \& Lucas, H. L. (1956). F. Anim. Sci. 15, 1256.

Mohrman, R. K., Albert, W. W., Neumann, A. L. \& Mitchell, G. E. Jr. (1959). F. Anim. Sci. 18, 1489.

Moir, R. J. \& Somers, M. (1957). Aust. Y. agric. Res. 8, 253.

Payne, W. J. A. (1966). Nutr. Abstr. Rev. 36,653.

Putnam, P. A., Gutierrez, J. \& Davis, R. E. (1961). F. Dairy Sci. 44, 1364.

Rakes, A. H., Hardison, W. A., Albert, J., Moore, W. E. C. \& Graf, G. C. (1957). F. Dairy Sci. 40, I62 r. Rakes, A. H., Lister, E. E. \& Reid, J. T. (ז96r). F. Nutr. 75, 86.

Raleigh, R. J. \& Wallace, J. D. (1965). 7. Anim. Sci. 24, 595.

Rhodes, R. W. \& Woods, W. (1962). F. Anim. Sci. 21, 108.

Satter, L. D. \& Baumgardt, B. R. (r962). F. Anim. Sci. 21, 897.

Sutherland, T. M., Gupta, B. N., Reid, R. S. \& Murray, M. G. (1963). Proc. int. Congr. Nutr. vi, Edinburgh, p. 579. 